\title{
SEMANTIC NETWORK OF THE WORD ASSOCIATION IN THE FIELD OF LAW
}

\author{
Arti Prihatini \\ Universitas Muhammadiyah Malang \\ e-mail: artiprihatini@umm.ac.id
}

\begin{abstract}
Word association can be utilized for identifying semantic network and describing a person's point of view and prior knowledge. This study is aimed at discussing two focuses, (1) the categorization of response word and (2) language factors that form semantic networks from the response words of word association in the field of law. This study uses a qualitative approach as a type of descriptive case study research. Data collection was conducted by using a word association questionnaire. Results show that the stimulus words in the form of nouns are the most responded by nouns, verbs are the most responded by nouns, and adjectives are responded more by adjectives. Overall, responses in the form of nouns are $64.71 \%$, verbs are $17.70 \%$, and adjectives are $17.58 \%$. The responses in the form of nouns are related to the semantic relations of argument and predication, while the adjective responses tend to be related to other adjectives in the unity of the semantic network. The response words form the semantic network based on language factors, namely (1) lexical factors that consist of meaning relationship, connotation of meaning, concreteness and abstractness and (2) grammatical factors that consist of syntagmatic-paradigmatic and predication-argument relationship.
\end{abstract}

Keywords: semantic network, word association, mental lexicon

\section{JARINGAN SEMANTIK DALAM ASOSIASI KATA BIDANG HUKUM}

\begin{abstract}
Abstrak
Asosiasi kata dapat digunakan untuk mengidentifikasi jaringan semantik dan untuk mendeskripsikan sudut pandang dan pengetahuan awal seseorang. Penelitian ini bertujuan membahas dua fokus penelitian, yaitu (1) kategori kata respon dan (2) faktor lingual pembentuk jaringan semantik yang berpengaruh terhadap respon asosiasi kata dalam bidang hukum. Penelitian ini menggunakan pendekatan kualitatif yang berjenis penelitian studi kasus deskriptif. Pengumpulan data dilakukan dengan angket asosiasi kata. Berdasarkan kategori respon kata, hasil penelitian menunjukkan bahwa kata stimulus berupa nomina paling banyak direspon dengan nomina, verba paling banyak direspon dengan nomina, sedangkan ajektiva lebih banyak direspon dengan ajektiva juga. Secara keseluruhan, respon berupa nomina sebesar $64.71 \%$, respon berupa verba $17.70 \%$, respon berupa ajektiva sebesar $17.58 \%$. Banyaknya respon berupa nomina tersebut berkaitan dengan hubungan semantis argumen dan predikasi, sedangkan respon ajektiva cenderung berkaitan dengan ajektiva lain dalam kesatuan rangkaian jaringan
\end{abstract}


semantiknya. Secara umum, jenis kata yang dipilih sebagai respon asosiasi kata tersebut mempertimbangkan beberapa faktor lingual, yaitu (1) faktor leksikal yang mencakup relasi makna, konotasi makna, serta sifat konkret dan abstrak; dan (2) faktor gramatikal yang mencakup hubungan sintagmatik-paradigmatik serta hubungan predikasi-argumen.

Kata Kunci: jaringan semantik, asosiasi kata, leksikon mental

\section{PENDAHULUAN}

Terdapat hubungan antara pikiran dan bahasa. Gagasan seseorang yang ingin disampaikan seseorang akan diwujudkan dalam bentuk kata-kata, baik bunyi maupun tulisan, dengan menggerakkan saraf sensorik pada alat artikulator hingga terproduksi secara lisan/tulis. Sebagaimana disampaikan Yun dan Park (2018:1), bahasa merefleksikan pikiran seseorang. Pada konteks ini, pikiran yang direpresentasikan oleh bahasa tersebut dapat berupa pengetahuan atau sudut pandang terhadap sesuatu.

Selain itu, bahasa juga merepresentasikan mental lexicon (kosakata mental) yang dimiliki oleh seseorang. Mental lexicon adalah perbendaharaan kosakata yang diketahui dan dipahami oleh seseorang. Hal itu didapatkan seseorang baik melalui proses pemerolehan maupun pembelajaran bahasa. Sebagaimana dikemukakan Jackendoff (2002:130) bahwa leksikon mental adalah penyimpan katakata dalam ingatan jangka panjang yang berkaitan dengan tata bahasa dalam menyusun frasa dan kalimat, berisi informasi seperti bagian ucapan (rumah adalah kata benda), denotasi (seekor anjing adalah binatang), pengucapan (balon dilafalkan b-lōōn '), makna afektif (kue adalah sesuatu yang saya sukai), dan sebagainya.

Mental lexicon tersusun dalam otak manusia dalam berbagai folder-folder yang di dalamnya terdapat file-file kata, misalnya folder makanan dan folder nama hewan. Antara satu folder kosakata dengan folder kosakata lain juga memiliki hubungan. Hal itu dapat dibuktikan ketika satu kata dibaca atau didengarkan, seseorang dapat merespon kata tersebut dengan kata lain yang memiliki hubungan dengan kata tersebut. Misalnya, jika kata makan disebutkan, dalam pikiran seseorang akan terlintas kata lapar dan nasi. Kata lapar muncul karena secara semantis, seseorang makan karena lapar. Sementara itu, kata nasi muncul karena makanan pokok yang biasa dikonsumsi adalah nasi. Hubungan antarkata tersebut jika dihubungkan akan membentuk semacam jaring-jaring laba-laba. Hal itu disebut dengan jaringan semantik (semantic network). Berkaitan dengan hal itu, Steyvers dan Tenenbaum (2005:43) menyatakan bahwa berdasarkan sudut pandang jaringan semantik, makna tidak terpisah dari struktur karena makna dari suatu konsep memiliki hubungan dengan konsep lainnya. Pada contoh yang disebutkan, kata lapar disebutkan setelah membaca/mendengar kata makan karena 
ada hubungan kausal (sebab-akibat) antara keduanya. Sementara itu, kata nasi disebutkan karena nasi dapat menduduki argumen dalam dari predikasi makan. Sebagaimana dikemukakan Fernandez dan Cairns (2011: 65) bahwa representasi leksikal terhadap verba adalah informasi subkategorisasi, yakni verba akan menentukan apakah ia perlu diikuti suatu argumen atau tidak.

Satu cara yang dapat dilakukan untuk menganalisis jaringan semantik adalah tes asosiasi kata (word association test). Tes asosiasi kata dilakukan dengan menunjukkan satu kata stimulus lalu seseorang diminta untuk menyebutkan satu kata lain setelah mendengar/membaca kata stimulus tersebut (Istifçi, 2010: 360; Rapp, 2014: 2030; dan Playfoot, 2018: 607). Berkaitan dengan hal itu, Sukartiningsih (2010: 213) menyampaikan bahwa asosiasi kata/makna merupakan gejala konstruksi semantik suatu kata. Dengan demikian, Van Rensbergen, Storms, dan De Deyne (2015:1718) menegaskan bahwa asosiasi kata dapat mengidentifikasi beberapa faktor yang menunjukkan beberapa properti yang cenderung dimiliki oleh konsep-konsep yang saling terhubung.

Sementara itu, Bahar dan Hansell (2015:352) menjelaskan bahwa pada tes asosiasi kata bebas hal penting yang perlu dijelaskan adalah respon terhadap setiap kata stimulus. Pada hasil tes asosiasi kata tersebut, dapat diketahui keterhubungan dan atau kesenjangan semantik antara satu kata dengan kata yang lain. Kata yang saling berhubungan diproses dengan waktu yang lebih cepat dibandingkan dengan kata yang kurang atau tidak memiliki hubungan. Berkaitan dengan hal itu, secara simbolis Meara (2009:1617) menyebutkan bahwa asosiasi kata mendeskripsikan kamus yang terorganisasi dalam otak manusia.

Respon asosiasi kata antara satu orang dengan orang lain tidak selalu sama. Hal itu disebabkan oleh perbedaan pengalaman, pikiran, dan perasaan seseorang. Selain itu, perbedaan lingkungan sosial, budaya, dan usia juga berpengaruh pada respon asosiasi kata yang dihasilkannya. Berkaitan dengan hal itu, Kostova dan Radoynovska (2010:62) menyebutkan respon terhadap kata stimulus diambil dari sekelompok asosiasi yang sebagian besar didasarkan pada pendidikan dan pengalaman sains.

Respon asosiasi kata dari sekelompok orang dapat didominasi oleh satu kata, tetapi ada pula respon kata yang unik yang disebutkan oleh satu orang saja. Hal itu berkaitan dengan temuan Spiteri (2005:60) bahwa respon asosiasi kata dapat berupa kata unik yang disebutkan satu orang saja atau kata umum yang disebutkan oleh lebih dari satu orang. Berdasarkan hubungan antara kata stimulus dengan kata respon, Spiteri (2005:60) menyebutkan beberapa bentuk hubungan tersebut, yaitu (1) tipe/bentuk dari, (2) partisipan/anggota/pendukung, (3) komponen/bagian dari, (4) tujuan, (5) tindakan/aktivitas, (6) kosakata ekuivalen/sinonim, (7) tempat/lokasi. Sementara itu, Meara (2009: 6) menjelaskan bahwa asosiasi kata pada umumnya terdiri atas dua jenis, yaitu (1) asosiasi paradigmatik dan (2) asosiasi sintagmatik. Pada asosiasi paradigmatik, kata stimulus makan akan direspon minum. Pada asosiasi sintagmatik, kata stimulus makan akan direspon dengan 
kata nasi.

Setiap bidang ilmu memiliki istilahistilah yang digunakan untuk menjelaskan konsep atau teori yang berhubungan dengan bidang ilmu tersebut. Satu di antara bidang ilmu yang memiliki istilah khusus adalah bidang hukum. Berdasarkan observasi dan wawancara yang telah dilakukan pada mahasiswa Fakultas Hukum Universitas Muhammadiyah Malang, istilah bidang hukum beraneka ragam, baik dalam hukum pidana maupun perdata. Istilah-istilah tersebut dapat ditemui secara umum dalam berita, sedangkan secara khusus dipelajari dalam perkuliahan di fakultas hukum. Akan tetapi, mahasiswa mengalami kendala dalam menguasai seluruh istilah hukum karena mahasiswa tersebut masih baru menempuh perkuliahan (semester satu).

Terdapat beberapa penelitian yang relevan dengan penelitian ini. Kwong (2013) meneliti mental lexicon bahasa Cina dengan asosiasi kata. Penelitiannya menemukan adanya dominasi kata bersilaba dua, konsep nominal, dan asosiasi kolokasi. Bahar dan Hansell (2014) meneliti hubungan antara faktor psikologis dan efeknya terhadap performansi siswa dari pertanyaan kisi-kisi dan terhadap tes asosiasi kata pada bidang biologi. Hasil penelitiannya menunjukkan bahwa (1) terdapat kondisi yang tumpang tindih antara bidang yang independen, kapasitas working memory yang tinggi, dan gaya berfikir divergen dengan bidang yang dependen, kapasitas working memory yang rendah, dan gaya berfikir yang konvergen dan (2) siswa yang independen memiliki performansi yang lebih baik dibandingkan dengan siswa yang dependen. Utsumi (2015) meneliti tiga properti jaringan makna, yaitu small word, scale-free, dan properti hierarkis pada jaringan semantik yang terbentuk dari model semantik distribusional. Utsumi menemukan bahwa jaringan yang terbentuk memiliki kesamaan properti dengan jaringan pada asosiasi kata. Selanjutnya, penelitian Playfoot et. al. (2016) menemukan bahwa asosiasi kata merefleksikan kata pertama yang diaktivasi partisipan dari daftar leksikon yang dimilikinya. Berdasarkan penelitianpenelitian tersebut, relevansinya dengan penelitian ini adalah sama-sama menggunakan asosiasi kata untuk menganalisis objek yang diteliti. Namun, objek yang dianalisis berbeda dengan penelitian ini, yakni respon asosiasi kata bidang hukum untuk mengetahui jaringan semantik mahasiswa.

Berdasarkan latar belakang tersebut, diperlukan penelitian untuk mengidentifikasi skemata mahasiswa tersebut di bidang hukum. Sebagaimana dikemukakan Utsumi (2015: 1) bahwa asosiasi kata bebas dapat merefleksikan pengetahuan leksikal manusia. Chomsky (2012: xv) juga mengungkapkan bahwa bahasa manusia merefleksikan karakteristik kapasitas intelektual seseorang dan bahasa bisa menjadi cermin pikiran secara langsung. Hal itu dilakukan untuk mendeskripsikan jaringan semantik pada respon asosiasi kata dalam bidang hukum pada mahasiswa Fakultas Hukum Universitas Muhammadiyah Malang. Hal itu sesuai dengan Bucklin dan Daniel (2017:668) bahwa salah satu cara untuk menilai prakonsepsi yang dimiliki peserta didik tentang topik tertentu adalah dengan menggunakan teknik asosiasi. 
Pendidik dapat menggunakan tanggapan siswa untuk mempelajari bagaimana siswa memahami dan mengatur pengetahuan sebelumnya sehingga dapat dimanfaatkan dalam menyusun kegiatan pengajaran selanjutnya untuk menargetkan prakonsepsi yang diungkapkan dari topik tersebut.

Berkaitan dengan hal itu, Playfoot (2018:622) menyarankan bahwa analisis asosiasi kata dapat dikaitkan dengan efek frekuensi kata, sifat konkret/abstrak pada kata, kelas kata, dan kategori yang sering dianggap respon (paradigmatik dan sintagmatik) untuk memberikan kedalaman pemahaman yang lebih besar mengenai struktur dan dinamika leksikon. Oleh karena itu, penelitian ini difokuskan pada kelas kata stimulus nomina, verba, dan ajektiva yang akan dianalisis klasifikasi respon asosiasi kata yang lebih terfokus pada analisis asosiasi kata yang diungkapkan Playfoot, khususnya berdasarkan kelas kata, frekuensi kata, serta paradigmatik dan sintagmatik.

\section{METODE}

Penelitian ini menggunakan pendekatan kualitatif. Jenis penelitian ini adalah studi kasus deskriptif. Pendekatan dan jenis penelitian tersebut dipilih karena penelitian ini untuk membahas respon asosiasi kata bidang hukum secara objektif dan mendalam dalam bentuk uraian-uraian yang dilandasai teori semantik dan psikolinguistik. Data penelitian ini adalah respon asosiasi kata bebas yang berupa kata-kata. Data penelitian ini bersumber dari hasil angket yang telah diisi oleh responden, yakni 80 mahasiswa angkatan 2018/2019 Fakultas
Hukum Universitas Muhammadiyah Malang. Pengumpulan data dilakukan dengan teknik angket yang di dalamnya memuat tabel yang berisi kolom kata stimulus dan kolom kata respon yang harus diisi oleh responden dengan satu kata pertama yang terlintas di pikiran responden. Analisis data dilakukan dalam tiga tahap, yaitu reduksi data, penyajian data, serta penarikan kesimpulan dan verifikasi temuan. Analisis data dilakukan pada kata respon dengan mengidentifikasi hubungan antara kata stimulus dengan kata respon. Pada proses pengumpulan data, instrumen penelitian yang digunakan adalah lembar angket, sedangkan pada proses analisis data, panduan analisis data digunakan sebagai instrumen penelitian.

\section{HASIL DAN PEMBAHASAN Hasil}

Hasil penelitian dijelaskan berdasarkan dua fokus, yaitu kategori kata respon dan faktor lingual pembentuk jaringan semantik dari hasil respon asosiasi kata bidang hukum. Berdasarkan data yang ditemukan, hasil penelitian menunjukkan bahwa kategori kata respon yang dihasilkan adalah nomina, verba, dan ajektiva sebagaimana disajikan pada Tabel 1.

Tabel 1 menunjukkan bahwa kata stimulus berupa nomina dan verba adalah yang paling banyak direspon dengan nomina. Hal itu menunjukkan adanya hubungan yang erat antara nomina dengan nomina dan verba dengan nomina. Jika ditinjau dari hubungan semantisnya, nomina dengan nomina sama-sama berkedudukan sebagai argumen, sedangkan verba 
Tabel 1 Kategori Respon Kata pada Asosiasi Kata Bidang Hukum

\begin{tabular}{llccc}
\hline \multirow{2}{*}{ Kata Stimulus } & \multicolumn{3}{c}{ Persentase Kata Respon } \\
\cline { 3 - 5 } Nomina & Hakim & Nomina & Verba & Ajektiva \\
& Penyidik & 58.02 & 24.69 & 17.28 \\
& Sertifikat & 73.42 & 24.05 & 2.53 \\
& Penggelapan & 92.94 & 0.00 & 7.06 \\
\multirow{3}{*}{ Verba } & Warisan & 73.17 & 10.98 & 15.85 \\
& Bela & 92.77 & 2.41 & 4.82 \\
& Dakwa & 73.42 & 16.46 & 10.13 \\
& Bersaksi & 86.49 & 13.51 & 0.00 \\
& Disita & 50.00 & 36.25 & 13.75 \\
\multirow{3}{*}{ Ajektiva } & Menangkap & 50.63 & 44.30 & 5.06 \\
& Adil & 73.07 & 21.79 & 5.12 \\
& Rujararata & 29.76 & 7.14 & 63.10 \\
& & 22.89 & 10.84 & 66.27 \\
& & 64.71 & 17.70 & 17.58 \\
\hline
\end{tabular}

dengan nomina berkedudukan sebagai predikasi dan argumen. Sementara itu, kata stimulus berupa ajektiva lebih banyak direspon dengan ajektiva juga yang memiliki hubungan semantis dalam rangkaian kesatuan jaringan semantiknya.

Faktor lingual berpengaruh terhadap respon asosiasi kata sehingga membentuk pola jaringan semantik pada bidang hukum. Pola jaringan semantik sebagaimana disajikan pada Gambar 1.

Pada Gambar 1, dapat dijelaskan bahwa terdapat faktor yang berpengaruh terhadap respon asosiasi kata bidang hukum. Pada penelitian ini, respon asosiasi kata dianalisis berdasarkan jenis katanya. Berdasarkan data yang ditemukan, secara umum nomina dan verba cenderung direspon dengan nomina, sedangkan ajektiva cenderung direspon dengan ajektiva pula. Untuk membentuk jaringan semantik, jenis kata yang dipilih sebagai respon asosiasi kata tersebut mempertimbangkan beberapa faktor lingua, yaitu (1) faktor leksikal mencakup relasi makna, konotasi makna, dan sifat konkret dan abstrak pada kata dan (2) faktor gramatikal mencakup hubungan sintagmatik-paradigmatik dan hubungan predikasi-argumen.

\section{Pembahasan}

Pembahasan penelitian ini mencakup dua hal, yaitu (1) kategori kata respon dan (2) faktor lingual pembentuk jaringan semantik yang berpengaruh terhadap respon asosiasi kata bidang hukum. Kedua fokus tersebut dijelaskan sebagai berikut. 


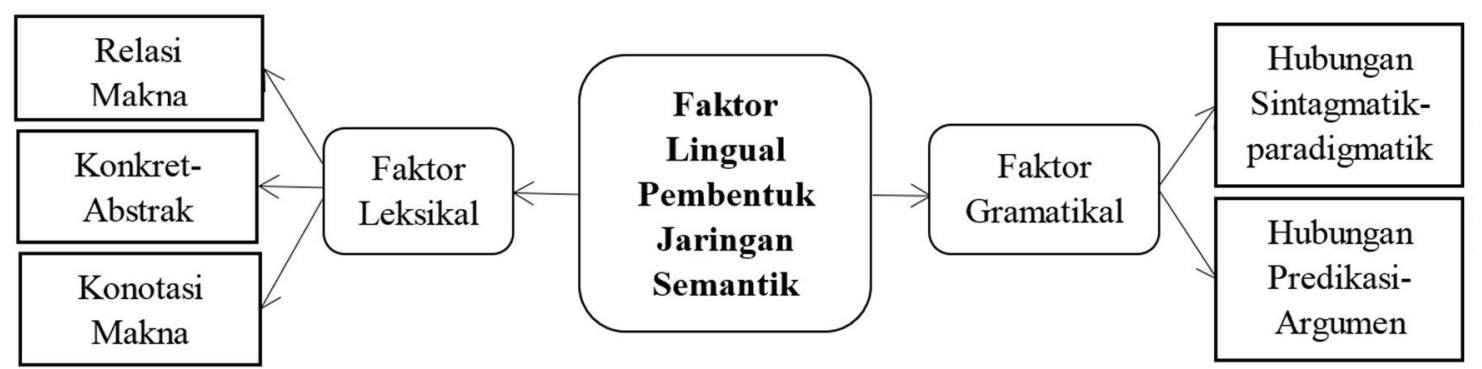

\section{Gambar 1. Faktor Lingual Pembentuk Jaringan Semantik dalam Asosiasi Kata pada Bidang Hukum}

\section{Kategori Kata Respon pada Asosiasi Kata}

\section{Bidang Hukum}

Penelitian ini menggunakan 12 kata stimulus, yaitu hakim, penyidik, sertifikat, penggelapan, warisan, bela, dakwa, bersaksi, disita, menangkap, adil, dan jujur. Berdasarkan kelas kata, kata-kata stimulus terdiri atas tiga kelas, yaitu (1) nomina atau kata benda (hakim, penyidik, sertifikat, penggelapan), (2) verba atau kata kerja (bela, dakwa, bersaksi, disita, dan menangkap) serta (3) ajektiva atau kata sifat (jujur dan adil). Ketiga jenis kata itu dipilih karena merupakan kata/morfem bebas yang maknanya dapat dipahami secara umum oleh masyarakat, termasuk mahasiswa.

Berdasarkan kata-kata stimulus tersebut, responden menuliskan kata respon yang pertama terlintas di pikiran. Berdasarkan data yang ditemukan, hasil penelitian menunjukkan bahwa kata respon yang dihasilkan adalah nomina, verba, dan ajektiva. Kata stimulus berupa nomina dan verba paling banyak direspon dengan nomina. Hal itu menunjukkan adanya hubungan yang erat antara nomina dengan nomina dan verba dengan nomina. Jika ditinjau dari hubungan semantisnya, nomina dengan nomina sama-sama berkedudukan sebagai argumen, sedangkan verba dengan nomina berkedudukan sebagai predikasi dan argumen. Sementara itu, kata stimulus berupa ajektiva lebih banyak direspon dengan ajektiva juga yang memiliki hubungan semantis dalam rangkaian kesatuan jaringan semantiknya. Di sisi lain, jenis kata lainnya, seperti numeralia, preposisi, atau konjungsi, tidak muncul sebagai respon kata karena numeralia tidak memiliki hubungan predikasi-argumen dengan nomina, verba, atau ajektiva, sehingga kecil peluangnya muncul sebagai respon kata. Sementara itu, preposisi dan konjungsi tidak muncul sebagai respon kata karena keduanya merupakan kata tugas yang tidak punya makna sendiri dan juga tidak bisa berdiri sendiri serta tidak memiliki hubungan predikasi-argumen dengan kata-kata stimulus tersebut. Jadi, dapat disimpulkan bahwa respon kata pada asosiasi kata adalah kata konten, sedangkan kata tugas/fungsi tidak ditemukan. Hal itu berkaitan dengan pernyataan Fernandez dan Cairns (2011: 64) sebagai berikut. 
Kata konten dapat berupa nomina, verba, ajektiva, dan adverbia, sedangkan kata tugas/fungsi merupakan penanda gramatikal antara lain: prposisi, konjungsi, determiner, dan lain-lain. Kata konten disebut juga kelas kata terbuka karena dapat bertambah seiring berjalannya waktu dalam leksikon suatu bahasa, sedangkan kata tugas/ fungsi disebut kelas tertutup karena tidak dapat bertambah. Kata konten dan kata tugas disimpan secara terpisah dan diakses dengan cara yang berbeda.

Oleh karena itu, kata stimulus yang tergolong kata konten tersebut direspon dengan kata konten juga karena berada dalam satu set penyimpanan yang sama dalam otak.

Untuk lebih jelasnya, hasil penelitian diuraikan dalam tiga bagian, yaitu (1) respon terhadap nomina stimulus, (2) respon terhadap verba stimulus, dan (3) respon terhadap ajektiva stimulus sebagai berikut.

Pertama, respon terhadap nomina stimulus. Nomina yang digunakan sebagai kata stimulus terdiri atas dua jenis, yaitu (1) nomina konkret berupa nomina persona hakim, penyidik, dan nomina nonpersona sertifikat dan (2) nomina abstrak pada kata penggelapan dan warisan. Nomina merupakan suatu entitas. Helbig (2006: 45) menyatakan bahwa suatu entitas dapat bersifat konkret seperti rumah dan kaki atau abstrak seperti hukum dan teori. Baik nomina konkret maupun nomina abstrak paling banyak direspon dengan nomina juga. Hal itu membuktikan bahwa pada jaringan semantik, nomina memiliki hubungan semantik yang dekat dengan nomina juga dibandingkan dengan jenis kata yang lain.

Respon berupa verba terjadi karena hubungan predikasi-argumen antara keduanya, yakni verba sebagai predikasi dan nomina sebagai argumennya. Di sisi lain, respon berupa ajektiva terjadi karena ajektiva menjelaskan karakteristik yang melekat dalam nomina. Sebagaimana dikemukakan Helbig (2006: 59) bahwa suatu objek (nomina) memiliki hubungan semantis dengan properti karakterisasi kualitatif yang berupa ajektiva atau nomina abstrak. Berdasarkan data yang ditemukan, rata-rata nomina direspon dengan ajektiva hanya berkisar 2-17\% saja, sedangkan nomina direspon dengan verba berkisar $2-24 \%$. Hal itu juga sesuai dengan pernyataan Helbig (2006: 59) bahwa suatu objek (nomina) memiliki hubungan yang primer dengan verba tindakan dan verba keadaan dan hubungan hubungan yang sekunder dengan ajektiva dan nomina abstrak.

Respon terhadap Nomina Stimulus berupa Nomina Konkret: Persona. Nomina persona paling banyak direspon dengan nomina persona juga lalu verba dan ajektiva. Hal itu tampak pada kata stimulus hakim yang direspon dengan nomina persona jaksa, penggugat, saksi, dan Tuhan. Nomina persona hakim juga banyak direspon dengan nomina persona sinonimnya, yaitu penegak hukum, penegak keadilan, orang yang menetapkan hukuman, pengadil, pemimpin persidangan, penegak, pemimpin, pemutus keputusan, dan pemutus. Berkaitan dengan hal itu, penelitian Kuperberg et. al. (2007: 226) menemukan bahwa hubungan tematik dipengaruhi 
oleh fitur-fitur semantik dasar seperti animacy, bukan hanya hubungan leksikosemantis yang dekat.

Berkaitan dengan hal itu, De Hoop (2009: 41) menyatakan bahwa animacy berkontribusi terhadap prominence dari suatu frasa nomina. Meskipun animacy bukan merupakan kategori linguistik, animacy berpengaruh terhadap bahasa dalam beberapa hal. Comrie (1989, dalam De Hoop, 2009: 42) membedakan animacy menjadi tiga jenis, yaitu (1) manusia, (2) hewan (animate), dan (3) benda tidak bernyawa (inanimate). Dengan demikian, dapat dikatakan bahwa nomina persona bersifat animate yang menjadi kata stimulus memiliki hubungan tematik dan hubungan jaringan semantik yang dekat dengan nomina persona juga. Berdasarkan data yang ditemukan, respon nomina persona tersebut berbentuk sinonim atau definisi dari nomina stimulusnya. Berkaitan dengan hal itu, Prihatini (2018:13) menemukan bahwa nomina persona dapat saling bertukar tempat dengan nomina persona lainnya karena efek kebernyawaan (animacy) pada kedua kata tersebut.

Selain direspon dengan nomina, kata stimulus nomina persona juga direspon dengan verba meskipun jumlahnya tidak sebanyak respon nomina. Berdasarkan data yang ditemukan, respon berupa verba pada umumnya bermakna tindakan, sedangkan verba keadaan sedikit ditemukan. Verba tindakan yang banyak ditemukan adalah yang berimbuhan meatau me- + -kan yang membentuk verba aktif transitif, sedangkan imbuhan -kan dan di- + -kan sedikit sekali ditemukan. Pada kata stimulus hakim, kata respon verba yang ditemukan adalah mengadili, memutuskan, menghukum, menilai, menjatuhkan hukuman, dan menyatu. Hal itu membuktikan bahwa pada jaringan semantik, nomina persona memiliki hubungan semantik yang dekat dengan verba tindakan aktif transitif yang merepresentasikan hubungan predikasi dan argumen yang erat.

Sementara itu, respon berupa ajektiva pada umumnya berupa sifat yang memiliki hubungan dengan nomina tersebut. Pada kata stimulus hakim, kata respon ajektiva yang ditemukan adalah adil, tegas, selalu benar, dan agung. Hal itu sesuai dengan pendapat Berdasarkan konotasi maknanya, respon ajektiva tersebut cenderung positif yang merepresentasikan nomina hakim, sedangkan respon ajektiva berkonotasi negatif tidak ditemukan. Sebagaimana dikemukakan Greenleaf et. al. (2004: 380-381) bahwa variasi kata positif dan negatif menunjukkan adanya perbedaan interpretasi dan asosiasi makna yang berbeda terhadap suatu kata. Oleh karena respon kata yang cenderung positif, dapat disimpulkan bahwa hal itu mengindikasikan adanya interpretasi dan asosiasi makna terhadap hakim yang cenderung positif pula. Temuan penelitian tersebut berkaitan dengan temuan penelitian Amrullah (2018:158) bahwa stigma positif atau negatif terhadap suatu kata dipengaruhi oleh budaya, gaya hidup, dan kebiasaan yang mempengaruhi pola pikir seseorang dan referen seseorang terhadap suatu konsep. Jadi, respon kata yang cenderung positif tersebut menunjukkan pola pikir dan referen kata bidang hukum pada mahasiswa yang cenderung positif pula. 
Respon terhadap Nomina Stimulus berupa Nomina Konkret: Nonpersona. Nomina konkret nonpersona paling banyak direspon dengan nomina abstrak, tetapi tak ditemukan respon berupa verba, sedangkan respon berupa ajektiva hanya terbatas. Pada kata stimulus sertifikat, respon lebih banyak berupa nomina abstrak yang merupakan sinonimnya, yaitu hak milik, surat pernyataan, bukti hak milik, piagam, kertas berharga, dan bukti berupa dokumen. Sementara itu, respon berupa nomina konkret juga ditemukan tetapi jumlahnya tidak sebanyak respon berupa nomina abstrak, seperti surat, kertas, dan surat resmi. Respon kata tersebut memiliki kedekatan makna dengan kata stimulus sertifikat. Sehubungan dengan hal itu, Fernandez dan Cairns (2011: 142) menjelaskan bahwa kata-kata diorganisasi dalam otak manusia berdasarkan maknanya sehingga kata-kata yang memiliki asosiasi yang dekat akan disimpan secara berdekatan. Seseorang memilih kata yang memiliki kesamaan kelas gramatikal -dalam hal ini adalah nomina- dan yang memiliki persamaan pada banyak aspek makna terhadap kata stimulus.

Respon terhadap Nomina Stimulus berupa Nomina Abstrak. Nomina abstrak yang digunakan pada penelitian ini adalah penggelapan dan warisan. Berdasarkan data yang ditemukan, nomina abstrak tersebut paling banyak direspon dengan nomina abstrak juga. Berkaitan dengan hal itu, Piantadosi, Tily, dan Gibson (2011) menyatakan bahwa nomina abstrak secara statistik memiliki struktur kata yang lebih panjang dibandingkan nomina konkret dan mengandung lebih banyak konten informasi daripada nomina konkret. Konten informasi tersebut yang membedakan apakah suatu nomina konkret atau abstrak. Jadi, dapat disimpulkan bahwa nomina abstrak cenderung direspon dengan nomina abstrak juga karena mengandung konten informasi abstrak yang dalam jaringan semantik juga cenderung terhubung dengan konten informasi abstrak juga.

Respon berupa verba dan ajektiva sedikit ditemukan. Hal itu sesuai dengan pernyataan Helbig (2006: 59) bahwa nomina abstrak merupakan properti karakterisasi kualitatif suatu objek (nomina) yang bersifat sekunder yang terdiri atas karakteristik relasional, karakteristik fungsional, atribut/fitur, dan properti lainnya. Nomina abstrak berbeda peran dengan verba karena verba memiliki hubungan primer dengan suatu objek (nomina). Karena memiliki hubungan yang berbeda inilah, nomina abstrak tidak banyak direspon dengan verba, tetapi lebih banyak direspon dengan nomina abstrak juga.

Pada kata stimulus penggelapan, respon paling banyak adalah nomina abstrak yang memiliki beberapa relasi makna dengan kata stimulus, yaitu sinonim, hal, hipernim, dan persona, misalnya kasus, korupsi, dana, penipuan. Selain nomina abstrak, respon berupa ajektiva juga ditemukan. Penggelapan memiliki makna yan berkonotasi negatif. Responnya yang berupa ajektiva pun juga berkonotasi negatif, yaitu ilegal, kriminal, gelap, dan diam. Pada kata stimulus warisan, respon paling banyak juga berupa nomina abstrak, seperti harta, keturunan, peninggalan, hak, dan sebagainya. Kata stimulus warisan 
berkonotasi positif. Respon terhadap warisan sebagian besar juga berupa kata yang berkonotasi positif, seperti penerus, integritas, kekayaan, dan sebagainya. Berdasarkan temuan tersebut, dapat dikatakan bahwa kata stimulus nomina abstrak cenderung direspon dengan nomina abstrak juga. Kata stimulus nomina abstrak juga cenderung direspon dengan kata yang memiliki konotasi makna yang sama dengan kata stimulus tersebut. Hal itu membuktikan bahwa pada jaringan semantik, nomina abstrak memiliki kedekatan semantis dengan nomina abstrak juga. Selain itu, nomina abstrak yang berkonotasi positif juga cenderung memiliki kedekatan semantis dengan kata yang berkonotasi positif juga, begitu pula sebaliknya.

Kedua, respon terhadap verba stimulus. Kata stimulus verba yang digunakan pada penelitian ini bervariasi, yaitu kata dasar (bela, dakwa), kata turunan intransitif (bersaksi), dan kata turunan transitif (menangkap, dan disita). Berdasarkan data yang ditemukan, respon terhadap verba paling banyak adalah nomina. Respon berupa verba menduduki peringkat kedua, sedangkan respon berupa ajektiva hanya sebagian kecil saja. Hal itu membuktikan bahwa pada jaringan semantik, verba dasar maupun verba turunan memiliki kedekatan semantis dengan nomina, dilanjutkan dengan verba dan ajektiva. Sebagaimana dikemukakan Helbig (2006: 85) bahwa unsur paling penting dalam relasi semantik dalam suatu kalimat adalah verba. Verba dapat diibaratkan sebagai 'keranjang' utama yang menyimpan setiap konstituen dalam kalimat secara utuh. Hal itu sejalan dengan pernyataan Fernandez dan Cairns (2011: 65) bahwa verba merupakan pusat terbentuknya suatu kalimat dan klausa. Temuan penelitian tersebut menunjukkan adanya hubungan erat antara predikasi (verba) dengan argumen (nomina) karena verba menentukan nomina yang menyertainya.

Respon berupa nomina tersebut meliputi nomina persona dan nomina abstrak (hal atau proses). Respon berupa nomina persona memiliki hubungan predikasi-argumen dengan verba stimulus, baik argumen luar maupun argumen dalam. Misalnya, pada verba stimulus bela yang berperan sebagai predikasi, respon nomina personanya adalah pengacara yang dapat berperan sebagai argumen luar dan orang yang tidak bersalah yang dapat berperan sebagai argumen dalam sintagmatik. Berdasarkan hubungan predikasi dengan argumen dalam (objek), Helbig (2006: 57) menyatakan bahwa secara logis, objek (argumen) memiliki hubungan yang dekat dengan predikasi. Hubungan predikasi-argumen pada verba stimulus dan respon nomina persona tersebut hubungan sintagmatik.

Verba stimulus yang disajikan merupakan verba yang merepresentasikan tindakan. Verba respon juga sebagian besar merepresentasikan tindakan; hanya sedikit respon yang merepresentasikan keadaan. Helbig (2006: 59) menyatakan bahwa verba tindakan bersifat dinamis dan berubah secara temporal, sedangkan verba keadaan bersifat statis dan relatif stabil jika dibandingkan dengan verba tindakan. Hal itu menunjukkan bahwa pada jaringan semantik, verba stimulus yang merepresentasikan tindakan me- 
miliki kedekatan semantis dengan verba stimulus berupa tindakan pula. Kondisi tersebut juga menunjukkan adanya hubungan yang paradigmatik antara verba stimulus dengan verba respon. Hubungan paradigmatik tersebut juga berkaitan dengan kesejajaran antara verba stimulus dengan verba respon, yaitu kesejajaran jenis kata dan kesejajaran imbuhan yang digunakan. Contohnya adalah verba stimulus disita direspon dengan verba diambil karena keduanya sama-sama verba dan berimbuhan di-. Menurut Prihatini, Sunaryo, \& Nurchasanah (2016:852), hasil temuan menunjukkan bahwa verba pada kalimat monotransitif pasif di- menunjukkan adanya perpindahan frasa nomina penderita ke fungsi subjek. Akan tetapi, jika verba stimulus disita direspon dengan nomina uang, maka menunjukkan adanya hubungan sintagmatik.

Berdasarkan relasi maknanya, verba respon sebagian besar berupa sinonim dari verba stimulus. Hal itu menunjukkan bahwa pada jaringan semantis verba memiliki kedekatan semantis dengan verba yang merupakan sinonimnya. Temuan penelitian tersebut bertentangan dengan temuan penelitian yang dilakukan Crutch et. al. (2012: 2642) terhadap penderita afasia bahwa antonim dipahami secara signifikan dan lebih akurat karena pertentangan informasi (polarity) diproses secara efisien dan akurat dibandingkan dengan aspek-aspek lain dalam makna kata.

Respon berupa ajektiva pada umumnya merepresentasikan karakteristik yang berkaitan dengan verba stimulus. Misalnya, kata stimulus bela direspon dengan kata benar, jujur, tidak bersalah. Asosiasi kata tersebut dapat diinterpretasi bahwa seseorang membela sesuatu yang benar atau seseorang dibela karena ia jujur dan tidak bersalah.

Jika dibandingkan, nomina stimulus lebih banyak direspon dengan nomina juga. Akan tetapi, mengapa verba tidak banyak direspon dengan verba juga yang sama kategori katanya dan mengapa verba justru lebih banyak direspon dengan nomina. Selain karena adanya hubungan predikasi-argumen dengan nomina, hal itu juga disebabkan oleh verba pada dasarnya bersifat abstrak, sedangkan nomina ada yang abstrak dan ada juga yang konkret. Hal itu berkaitan dengan penelitian Fisher (2002: 268) bahwa verba bersifat abstrak yang berisi perspektif pada peristiwa yang tidak dapat diprediksi dengan hanya mengamati peristiwa itu dan dengan memahami niat yang mendasari peristiwa tersebut.

Ketiga, respon terhadap ajektiva stimulus. Berdasarkan data yang ditemukan, respon terhadap ajektiva paling banyak adalah ajektiva juga, khususnya yang memiliki hubungan semantis dengan ajektiva tersebut. Hal itu disebabkan ajektiva berperan secara sekunder terhadap nomina, sedangkan verba berperan secara primer terhadap nomina (Helbig, 2006: 59). Oleh karena itu, ajektiva stimulus paling banyak direspon dengan ajektiva pula, sedangkan respon berupa verba lebih sedikit ditemukan. Misalnya, pada kata stimulus adil yang cenderung bermakna positif, kata respon yang paling banyak ditemukan adalah ajektiva juga yang memiliki makna konotasi positif, seperti jujur, sejahtera, makmur, abadi, kasih sayang, 
bijaksana, aman, baik, dan curang. Hanya ada sedikit kata respon yang memiliki makna negatif, yaitu sulit dan curang. Pada kata stimulus jujur, kata responnya juga cenderung berkonotasi positif, yaitu baik, aman, benar, adil, terbuka, terpuji, tenang, bahagia, polos, bijak, setia, rendah hati, makmur, tanggung jawab. Tidak ditemukan data kata respon berkonotasi negatif pada kata stimulus jujur. Berdasarkan temuan tersebut, dapat dikatakan bahwa kata stimulus ajektiva cenderung direspon dengan ajektiva juga. Selain itu, kata stimulus ajektiva yang bermakna positif juga cenderung direspon dengan kata respon yang bermakna positif juga. Hal itu membuktikan bahwa pada jaringan semantik, kata-kata dengan jenis kata dan konotasi makna yang sama memiliki hubungan semantik yang dekat dibandingkan dengan kata yang tidak sama jenis dan konotasi maknanya.

Berdasarkan uraian temuan penelitian tersebut, kata respon memiliki hubungan semantis dengan kata stimulus. Kata respon tersebut jika diklasifikasikan, terdiri atas beberapa kluster yang saling terhubung dalam mental lexicon yang membentuk hierarki klasifikasi (Singleton, 2000: 170). Kluster tersebut menunjukkan adanya klasifikasi kata dalam mental lexicon yang saling terhubung sehingga respon pada asosiasi kata tidak dapat dikatakan muncul secara arbitrer, tetapi respon tersebut muncul secara terorganisasi dalam otak dengan mengaktivasi jaringan semantik dalam otak manusia. Sebagaimana ditemukan dalam penelitian Reilly, Hung, dan Westburry (2016: 1071) bahwa seseorang mengeksplorasi pemetaan bentuk kata ke pemetaan makna kata secara nonarbitrer.
Selain bersifat nonarbitrer, Pecher dan Raaijmakers (2004: 1211) mengatakan bahwa pengetahuan verbal disimpan dalam memori semantis, dipelajari, dan dimunculkan kembali secara otomatis. Jadi, dapat dikatakan bahwa respon asosiasi kata muncul secara otomatis, tetapi tidak bersifat nonarbitrer atau acak karena respon tersebut muncul karena adanya kedekatan hubungan makna dalam jaringan semantik pada mental lexicon seseorang. Pada penelitian ini, mahasiswa Fakultas Hukum merespon kata tersebut dari mental lexicon mereka yang juga terbentuk dari proses perkuliahan dan pengalamannya.

\section{Faktor Lingual Pembentuk Jaringan Semantik dalam Asosiasi Kata pada Bidang Hukum}

Berdasarkan hasil penelitian, terdapat dua faktor lingual yang menentukan jaringan semantik dalam asosiasi kata pada bidang hukum, yaitu faktor leksikal dan faktor gramatikal. Faktor leksikal berkaitan dengan struktur dan makna yang melekat pada kata, sedangkan faktor gramatikal berhubungan dengan keterkaitan antara satu konstituen dengan konstituen lainnya dalam pembentukan konstituen yang lebih besar. Faktor leksikal yang ditemukan mencakup relasi makna, konotasi makna, dan sifat konkret dan abstrak pada kata dan (2) faktor gramatikal mencakup hubungan sintagmatik-paradigmatik dan hubungan predikasi-argumen.

Relasi makna yang banyak ditemukan adalah sinonim. Misalnya, kata hakim direspon dengan sinonimnya, seperti penegak keadilan dan penentu keputusan persidangan. Respon kata yang digunakan 
berupa frasa dan mengandung konotasi positif. Pada penelitian Anshori (2018:167) tentang stigma negatif terhadap kata korupsi pada media cetak, ditemukan bahwa sinonim dimanfaatkan untuk pemberian penjulukan (labeling) terhadap pelaku atau perbuatan korupsi sehingga terbentuk stigma dan pencitraan yang buruk terhadap koruptor. Pada penelitian Anshori tersebut, konotasi yang terbangun bersifat negatif, sedangkan pada penelitian ini konotasi respon cenderung positif. Hal itu berkaitan dengan status mahasiswa Fakultas Hukum yang pada mendatang dapat berpotensi sebagai orang yang bekerja di bidang hukum (misalnya, hakim) yang secara idealnya dituntut untuk memiliki karakter positif dan menjalankan perannya dengan baik.

Selain itu, kata stimulus ajektiva juga cenderung direspon dengan sinonimnya. Sebagaimana ditemukan pada data, kata stimulus adil direspon dengan sinonimnya, yaitu sama rata, sesuai, seimbang, rata, sama, merata, setara, tidak pandang bulu, setimbang, imbang, dan sesuai porsi. Pada kata stimulus jujur, kata respon berupa sinonim yang ditemukan adalah apa adanya dan terbukti benar. Hal itu membuktikan bahwa pada jaringan semantik, kata-kata memiliki hubungan semantik yang dekat dengan sinonimnya dibandingkan dengan antonimnya. Selain itu, temuan penelitian tersebut menunjukkan bahwa mahasiswa Fakultas Hukum memiliki sudut pandang positif terhadap hal dan jabatan dalam bidang hukum karena mereka memosisikan diri sebagai generasi yang dapat berprofesi pada bidang tersebut.
Berkaitan dengan sifat konkret dan abstrak kata, kata stimulus konkret dapat direspon dengan kata yang konkret dan juga asbtrak. Begitu pula kata stimulus abstrak juga dapat direspon dengan kata yang konkret atau abstrak. Akan tetapi, kecencerungan konkret-abstrak pada respon asosiasi kata tersebut disebabkan oleh unsur-unsur semantis yang melekat pada kata tersebut. Misalnya, nomina konkret nonpersona paling banyak direspon dengan nomina abstrak. Selain itu, pada kata stimulus sertifikat, respon lebih banyak berupa nomina abstrak yang merupakan sinonimnya, yaitu hak milik, surat pernyataan, bukti hak milik, piagam, kertas berharga, dan bukti berupa dokumen. Sementara itu, respon berupa nomina konkret juga ditemukan tetapi jumlahnya tidak sebanyak respon berupa nomina abstrak, seperti surat, kertas, dan surat resmi.

Berkaitan dengan faktor gramatikal, terdapat dua temuan, yaitu hubungan sintagmatik-paradigmatik serta hubungan predikasi-argumen. Hubungan paradigmatiktampak pada kata stimulus yang direspon dengan kata yang memiliki kategori kata yang sama dan dapat menggantikan posisi kata stimulus tersebut dalam kedudukannya sebagai fungsi sintaktis dalam kalimat, misalnya kata stimulus penyidik direspon dengan kata polisi yang sama-sama berkategori nomina dan dapat berfungsi sebagai subjek atau objek dalam kalimat. Sementara itu, hubungan sintagmatik tampak ketika kata stimulus direspon dengan kata lain yang memiliki kategori kata yang berbeda sehingga kata stimulus dan kata respon tersebut dapat membentuk konstituen yang lebih besar seperti dalam kalimat. Contohnya adalah 
stimulus nomina hakim direspon dengan verba memutuskan. Hubungan sintagmatik ini memiliki keterkaitan dengan hubungan predikasi-argumen, khususnya ketika kata stimulus dan kata respon berpotensi berperan sebagai subjek atau objek dan predikat. Contohnya adalah verba stimulus menangkap yang berpotensi sebagai predikasi (predikat) direspon dengan nomina pencuri yang dapat berkedudukan sebagai argumen dalam (objek).

\section{SIMPULAN}

Berdasarkan uraian penelitian tersebut, dapat disimpulkan bahwa respon asosiasi kata bidang hukum lebih banyak direspon dengan nomina untuk kata stimulus berupa nomina dan verba. Sementara itu, ajektiva cenderung direspon dengan ajektiva pula. Hal itu menunjukkan bahwa jaringan semantik antara nomina dengan nomina dan nomina dengan verba cenderung erat karena keduanya memiliki hubungan yang primer. Di sisi lain, ajektiva tidak banyak direspon dengan nomina atau verba karena hubungan di antara ketiganya bersifat sekunder. Secara lebih khusus, pemilihan jenis kata respon juga memperhatikan relasi makna, konotasi makna, hubungan sintagmatik dan paradigmatik, hubungan predikasi dan argumen, serta sifat konkret dan abstrak dari suatu kata.

\section{UCAPAN TERIMA KASIH}

Ucapan terima kasih disampaikan kepada Pimpinan Universitas Muhammadiyah Malang dan Direktorat Penelitian dan Pengabdian Masyarakat (DPPM) Universitas Muhammadiyah Malang yang telah mendukung proses dan pelaksanaan penelitian ini.

\section{DAFTAR PUSTAKA}

Amrullah, L. (2018). Semantic Prototypes of Indonesian Staple Foods. Litera, 17(2), 153-161. 10.21831/1tr.v17i2. 14544

Anshori, D. S. (2018). Stigma Negatif Bahasa Korupsi dalam Pemberitaan Media Massa. Litera, 17(2), 162-174. 10.21831/ltr.v17i2.18581

Bahar, M., \& Hansell, M. H. (2000). The Relationship between Some Psychological Factors and Their Effect on the Performance of Grid Questions and Word Association Tests. Educational Psychology, 20(3), 349-364. https://www.tandfonline. com/doi/abs/ 10.1080/713663739.

Bucklin, C. J., \& Daniel, K. L. (2017). Using Word Associations as a Formative Assessment for Understanding Phylogenetics. The American Biology Teacher, 79(8), 668-670. https://abt. ucpress.edu/content/79/8/668. abstract.

Chomsky, N. (2012). Language and Mind Third Edition. Cambridge: Cambridge University Press.

Crutch, S. J., Williams, P., Ridgway, G. R., \& Borgenicht, L. (2012). The Role of Polarity in Antonym and Synonym Conceptual Knowledge: Evidence from Stroke Aphasia and Multidimensional Ratings of Abstract Words. Neuropsychologia, 50(11), 2636-2644. https://doi.org/ $10.1016 / \mathrm{j}$.neuropsychologia. 2012.07.015.

De Hoop, H. (2009). On (In)animate Noun Phrases. In A. Giannakidou \& M. Rathert (eds.), Quantification, Definiteness \& Nominalization. Oxford: Oxford University Press. 
Fernandez, E. M. dan Cairns, H. S. (2011). Fundamentals of Psycholinguistics. West Sussex: Wiley Blackwell.

Fisher, C., (2002). The Role of Abstract Syntactic Knowledge in Language Acquisition: A Reply to Tomasello (2000). Cognition, 82(3), 259-278. https://doi.org/10.1016/S00100277(01)00159-7.

Greenleaf, C., Starks, M., Gomez, L., Chambliss, H., \& Martin, S. (2004). Weight-Related Words Associated with Figure Silhouettes. Body Image, 1(4), 373-384. https://doi. org/10.1016/j.bodyim.2004.10.004.

Helbig, H. (2006). Knowledge Representation and The Semantics of Natural Language. Berlin: Springer.

Istifçi, I. (2010). Playing With Words: A Study on Word Association Responses. Uluslararasi Sosyal Arastırmalar Dergisi (The Journal of International Social Research). 3(10), 360-368. http://www. sosyalarastirmalar.com/cilt3 / sayi10pdf/istifci_ilknur.pdf .

Jackendoff, R. (2002). Foundations of Language: Brain, Meaning, Grammar, Evolution. New York: Oxford University Press.

Kostova, S. \& Radoynovska, B. (2010). Motivating Students' Learning Using Word Association Test and Concept Maps. Bulgarian Journal of Science and Education Policy (BJSEP), 4(1), 62-98. http://bjsep.org/getfile. php?id=66.

Kwong, Oi Yee. (2013). Exploring The Chinese Mental Lexicon with Word Association Norms. 27th Pacific Asia Conference on Language, Information, and Computation: 153-162. https://www. aclweb.org/anthology/Y13-1013.
Kuperberg, G. R., Kreher, D. A., Sitnikova, T., Caplan, D. N., \& Holcomb, P. J. (2007). The Role of Animacy and Thematic Relationships in Processing Active English Sentences: Evidence from Event-Related Potentials. Brain and Language, 100(3), 223-237. https://doi.org/10.1016/j. band1.2005.12.006.

Meara, P. M. (2009). Connected Words: Word Associations and Second Language Vocabulary Acquisition. Amsterdam, Philadelphia: John Benjamins Publishing.

Pecher, D. \& Raaijmakers, J. G. W. (2004). Priming forNew Associations in animacy decision: Evidence for Context Dependency. The Quarterly Journal of Experimental Psychology 57A (7), 1211-1231. https://www. t a n d fon 1 ine.com / d o i / a b s /10.1080/02724980343000738.

Piantadosi, S. T.; Tily, H.; \& Gibson, E. (2011). Reply to Reilly and Kean: Clarifications on Word Length and Information Content. Proceedings of the National Academy of Sciences, 108 (20), E109-E109. https://www. pnas.org/content/108/20/E109. short.

Playfoot, D., Balint, T., Pandya, V., Parkes, A., Peters, M., \& Richards, S. (2018). Are Word Association Responses Really the First Words that Come to Mind? Applied Linguistics 39 (5), 607-624. https:// doi.org/10.1093/applin/amw015.

Prihatini, A., Sunaryo, S., \& Nurchasanah, N. (2016). Perpindahan Frasa Nomina Penderita dalam Kalimat Pasif Monotransitif. Jurnal Pendidikan: Teori, Penelitian, dan Pengembangan, 1(5), 844854. 
Prihatini, A. (2018). Perpindahan Frasa Nomina Benefactive ke Argumentposition dalam Kalimat Pasif Bitransitif pada Ragam Bahasa Lisan Anak Usia Prasekolah. Kembara, 4(2), 128-140.

Rapp, R. (2014). Using Word Familiarities and Word Associations to Measure Corpus Representativeness. In Proceedings of the Ninth International Conference on Language Resources and Evaluation (LREC-2014), Reykjavik, Iceland, 2029-2036. https://pdfs. semanticscholar.org/64cf/349f87e9 85a51e30d5fcd5c9aac1de2ac54.pdf.

Reilly, J., Hung, J., \& Westbury, C. (2016). Non-Arbitrariness in Mapping Word Form to Meaning: Cross-Linguistic Formal Markers of Word Concreteness. Cognitive Science, 41 (4): 1071-1089. https:// onlinelibrary.wiley.com / doi / full/10.1111/cogs.12361.

Singleton, D. 2000. Language and The Lexicon: An Introduction. London: Arnold.

Spiteri, L. F. (2005). Word Association Testing and Thesaurus Construction: A Pilot Study. Cataloging \& Classification Quarterly 40(1), 55-78. https://www.tandfonline.com/doi/ abs/10.1300/J104v40n01_05.

Steyvers, M. \& Tenenbaum, J. B. (2005). The Large-Scale Structure of
Semantic Networks: Statistical Analyses and A Model of Semantic Growth. Cognitive Science 29, 41-78. https://onlinelibrary.wiley.com/ $\mathrm{d}$ o i / a b s / $10.1207 /$ s15516709cog2901_3.

Sukartiningsih, W. (2010). Konstruksi Semantis Kata pada Perkembangan Bahasa Indonesia Anak. Bahasa dan Seni, 38(2), 205-216.

Utsumi, Akira. (2015). A Complex Network Approach to Distributional Semantic Models. PLoS ONE, 10(8): e0136277. https://journals.plos. org / plosone / article?id=10.1371/ journal.pone.0136277.

Van Rensbergen, B., Storms, G., \& De Deyne, S. (2015). Examining Assortativity in The Mental Lexicon: Evidence from Word Associations. Psychonomic Bulletin \& Review, 22(6), 1717-1724. https://link.springer. com/article/10.3758/s13423-0150832-5.

Yun, E. \& Park, Y. (2018). Extraction of Scientific Semantic Networks from Science Textbooks and Comparison with Science Teachers' Spoken Language by Text Network Analysis. International Journal of Science Education, https://www.tandfonline. com/doi/ abs/10.1080/09500693.2 018.1521536 . 